Des Machines et des hommes

\title{
Les images sonores
}

Naissance du théâtre radiophonique

\section{Cécile Méadel}

\section{OpenEdition}

\section{Journals}

Édition électronique

URL : https://journals.openedition.org/tc/728

DOI : $10.4000 /$ tc. 728

ISSN : 1952-420X

Éditeur

Éditions de l'EHESS

\section{Édition imprimée}

Date de publication : 1 novembre 1991

ISSN : 0248-6016

\section{Référence électronique}

Cécile Méadel, «Les images sonores », Techniques \& Culture [En ligne], 16 | 1991, mis en ligne le 10 janvier 2006, consulté le 29 septembre 2022. URL : http://journals.openedition.org/tc/728 ; DOI : https://doi.org/10.4000/tc.728

Ce document a été généré automatiquement le 29 septembre 2022.

Tous droits réservés 


\section{Les images sonores}

Naissance du théâtre radiophonique

\section{Cécile Méadel}

